\title{
A Review on The Phytochemical and Pharmacological Properties of The Ayurvedic Drug Vayugulika
}

\author{
Susan Jose* \\ Research scholar, Maharajas college, Ernakulam, India
}

\begin{abstract}
Article Info

Volume 8, Issue 3

Page Number: 304-316

Publication Issue :

May-June-2021

\section{Article History}

Accepted : 01 June 2021

Published: 05 June 2021

Plants are very useful source of various bioactive compounds which have direct or indirect use in the treatment of various human ailments from the time immemorial, human civilization have been exploring and using various plants and plant products to cure the deadly diseases. Vayugulika is a medicine is formulated based on Kerala Ayurveda practice. It is used in treating indigestion, anorexia, hicup. Cold, cough, rhinitis, asthma and bronchitis Colic abdominal pain. Sprain, convulsions, epilepsy and nerve disorders. It is used as adjuvant along with other Ayurvedic medicines in wide variety of diseases. The phytomedicines are safe and environmental friendly. Infact many indigenous and local communities are immense reservoirs of traditional knowledge that can benefit biotechnology, agriculture, pharmaceutical development and health care. The present study intends to provide an overview of the phytochemical constituents present in the Ayurvedic medicine Vayugulika with special emphasis on their pharmacological action.
\end{abstract}

Keywords : Vayugulika, Ayurveda, Pharmacological property.

\section{INTRODUCTION}

Vayugulika is an Ayurvedic medicine used mainly in digestive and respiratory diseases. It is in tablet form. This medicine is formulated based on Kerala Ayurveda practice. It is also known as Kasthoryadi Gulika. This contains ingredients of herbal and mineral origin. The main indication of this medicine is Vayu Roga. It is administrated along with cumin seed decotion, Bhadrveradi kashayam or Nayopayam kashayam. It is used in treating indigestion, anorexia, hicup. Cold, cough, rhinitis, asthma and bronchitis Colic abdominal pain. Sprain, convulsions, epilepsy and nerve disorders. It is used as adjuvant along with other Ayurvedic medicines in wide variety of diseases. This medicine should only be taken strictly under medical supervision. In some people, if it is taken before food, it may cause gastric or stomach discomfort. Such a side effect can be overcome by taking it after food and drinking one cup of water. Special care is required while administrating this medicine to children and pregnant ladies. Men seeking infertility treatments better avoid this medicine, since it contains kshara as ingredient, which may harm wealthy and quantity of sperm. 
Vayugulika is used in treating indigestion, anorexia, hiccups, cold, cough, asthma, bronchitis, colic abdominal pain, sprain convulsions, epilepsy, and nervous disorders. It is used as adjuvant along with other ayurvedic medicine in wide variety of diseases. Bio medical actions are, removes excess mucus from the body, anti-inflammatory, reduces inflammation by acting on body mechanisms, antispasmodic, relives spasm of involuntary muscles. The present study intends to provide an overview of the phytochemical constituents present in the Ayurvedic medicine Vayugulika with special emphasis on their pharmacological action. Natural products are increasingly purported to exert potent beneficial actions to support health and may thus play a role in reducing synthetic drug use for the treatment of metabolic complications. This has lead to the identification and isolation of compounds from natural products with antioxidant activity against metabolic syndrome (Ghilani, 2005). The present study intends to provide an overview of the phytochemical constituents present in the Ayurvedic medicine Vayu gulika with special emphasis on their pharmacological actions.

\section{METHODS AND MATERIAL}

The present survey was carried out to get information about the medicinal plants used in the Ayurvedic drug "vayugulika". The informations were collected from ayurvedic medical practitioners and literature. So this study was aimed to know about the plants and plant parts used, and the phytochemicals responsible for pharmacologial effects.

\begin{tabular}{|c|c|c|c|}
\hline Sr.No. & PLANT & DESCRIPTION & $\begin{array}{l}\text { PART } \\
\text { USED }\end{array}$ \\
\hline 1 & CINNAMOMUM ZEYLANICUM & $\begin{array}{l}\text { The plant hardly reaches to a height more than } 30 \\
\text { feet and is bushy. Leaves of the plant are dark } \\
\text { green, ovate and deeply veined. The flowers of the } \\
\text { plant are small and yellowish to white coloured } \\
\text { with unpleasant odour and usually grow in } \\
\text { bunches. The tree bear dark purple berries. The } \\
\text { fruit is oval shaped and holds seeds in it. The bark } \\
\text { of younger tree is smooth and pale while bark of } \\
\text { older tree is brittle rough and brownish. }\end{array}$ & $\begin{array}{l}\text { Stem bark } \\
\text { Leaf }\end{array}$ \\
\hline 2 & 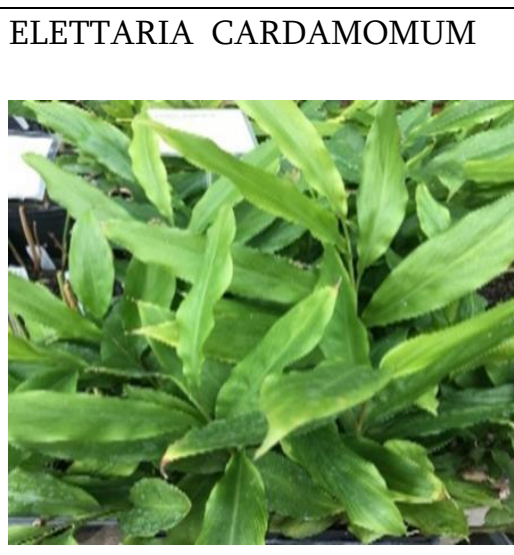 & $\begin{array}{l}\text { Cardamom is an herbaceous perennial grown for } \\
\text { its fruits. It is a clumping plant, shoots between } 10 \\
\text { and } 20 \text { arising from the rhizome. The shoots are } \\
\text { actually pseudo stems composed of overlapping } \\
\text { leaf sheaths. There are several additional flowering } \\
\text { shoots. The leaves are lanceolate and dark green in } \\
\text { colour. The plant produces flowers on a long } \\
\text { drooping pannicle and a capsule like fruit which is } \\
\text { green or yellow in colour. The fruit contains } 15- \\
20 \text { aromatic seeds. Cardamom reaches to a height } \\
\text { of } 5 \mathrm{~m} \text { and has an economic life span of } 10-15 \\
\text { years. }\end{array}$ & $\begin{array}{l}\text { Fruit } \\
\text { (Seed) }\end{array}$ \\
\hline
\end{tabular}




\begin{tabular}{|c|c|c|c|}
\hline Sr.No. & PLANT & DESCRIPTION & $\begin{array}{l}\text { PART } \\
\text { USED }\end{array}$ \\
\hline 3 & PIPER NIGRUM & $\begin{array}{l}\text { It is a spreading vine, rooting readily where } \\
\text { trailing stems touch the ground. The leaves are } \\
\text { alternate, entire; } 5 \text { to } 10 \mathrm{~cm} \text { long and } 3 \text { to } 6 \mathrm{~cm} \\
\text { across. The flowers are small, produced on } \\
\text { pendulous spikes } 4 \text { to } 8 \mathrm{~cm} \text { long at the leaf } \\
\text { nodes, the spikes lengthening up to } 7 \text { to entire } \\
\text { as the fruit matures. Pepper can grow in soil } \\
\text { that is neither too dry nor susceptible to } \\
\text { flooding. A single stem bears } 20 \text { to } 30 \text { fruiting } \\
\text { spikes. The harvest begins as soon as one or } \\
\text { two fruits at the base of the spikes begin to turn } \\
\text { red. }\end{array}$ & Fruit \\
\hline 4 & PIPER LONGUM & $\begin{array}{l}\text { The plant is slender, glabrous climber or } \\
\text { creeping shrub that spreads on ground striking } \\
\text { roots at each node. It produces two distinct } \\
\text { dimorphic branches-vegetative main branches } \\
\text { that creep on ground; and erect growing } \\
\text { reproductive axillary branches. The plant } \\
\text { flowers throughout the year and is dioecious in } \\
\text { nature with the male and female flowers } \\
\text { produced on different parts. Inflorescence is } \\
\text { spike, about } 35 \text { mm long and } 5 \text { mm thick, } \\
\text { composed of large numbers of minute greyish } \\
\text { green or darker grey fruits, which together } \\
\text { with the bracts that support them are } \\
\text { embedded in the elongated axis and the whole } \\
\text { being covered with greyish dust. }\end{array}$ & Fruit \\
\hline
\end{tabular}




\begin{tabular}{|c|c|c|c|}
\hline 5 & ZINGIBER OFFICINALE & $\begin{array}{l}\text { Ginger is a herbaceous perennial which grows } \\
\text { annual pseudo stems about a meter tall bearing } \\
\text { narrow leaf blades. The stems are upright and } \\
\text { leaves are narrow medium green leaves } \\
\text { arranged in two ranks on each stem. The plant } \\
\text { gets about } 4 \text { feet tall with wide and long leaves. } \\
\text { Ginger grows from an aromatic tuber like } \\
\text { rhizome which is warty and branched. The } \\
\text { inflorescence grows on separate stem from the } \\
\text { leaf stem and forms a dense spike, up to } 3 \text { inch } \\
\text { tall. Flowers are small and are yellow green in } \\
\text { colour. }\end{array}$ & Rhizome \\
\hline 6 & & $\begin{array}{l}\text { It is a plant with tuberous root, and is also a } \\
\text { herbaceous perennial reaching } 1 \mathrm{~m} \text { tall and } 0.5 \\
\mathrm{~m} \text { wide. It is a principal source of Indian } \\
\text { poison. The leaves are scattered, ovate - } \\
\text { reniform and the flowers are blue in colour } \\
\text { with purple veins, arranged in terminal } \\
\text { racemes. The plant has paired tuberous roots } \\
\text { with conical and elongated daughter tubers. } \\
\text { The fruit is capsule, composed of five follicles } \\
\text { and bears numerous seeds. It is a poisonous } \\
\text { herb but when used in purified form in small } \\
\text { quantities it has many health benefits. }\end{array}$ & $\begin{array}{l}\text { Tuberous } \\
\text { root }\end{array}$ \\
\hline 7 & 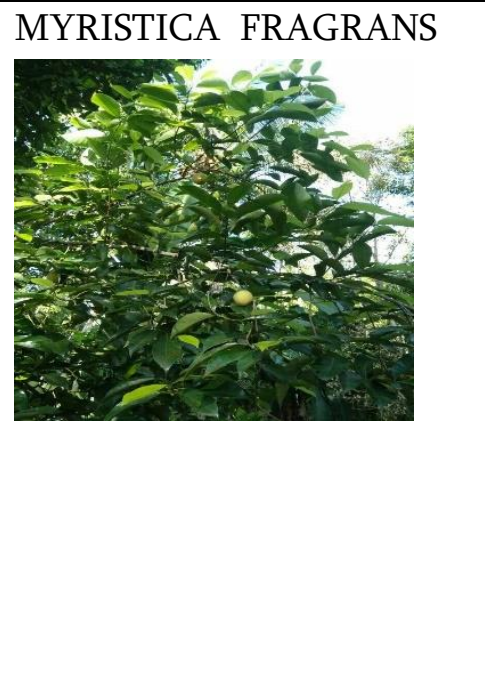 & $\begin{array}{l}\text { The Nutmeg tree has natural conical shape } \\
\text { with a grey - brown trunk and dark green } \\
\text { glossy leaves. The branches of the tree spread } \\
\text { in whorls and leaves are oval or lanceolate in } \\
\text { shape. Leaves are arranged alternately on the } \\
\text { branches and are smooth and lighter in colour } \\
\text { on the underside. Tree produces cluster of male } \\
\text { flowers while female flowers exist solitary or in } \\
\text { a cluster of three. It is dioecious. Fruit is } \\
\text { rounded and fleshy. The ripe fruit splits to } \\
\text { expose a single glossy purple - brown nut } \\
\text { enclosed by scarlet aril. }\end{array}$ & $\begin{array}{l}\text { Seed / } \\
\text { Leaves }\end{array}$ \\
\hline 8 & MALLOTUS PHILIPPENSIS & $\begin{array}{l}\text { Trees are small to medium sized monoecious in } \\
\text { nature. They grow up to } 25 \mathrm{~m} \text { in length and } \\
\text { with a bole up to } 50 \mathrm{~cm} \text { in diameter. Branchlets } \\
\text { are reddish brown. } \\
\text { Leaves are alternate and simple and appear to }\end{array}$ & Fruit \\
\hline
\end{tabular}




\begin{tabular}{|c|c|c|c|}
\hline & 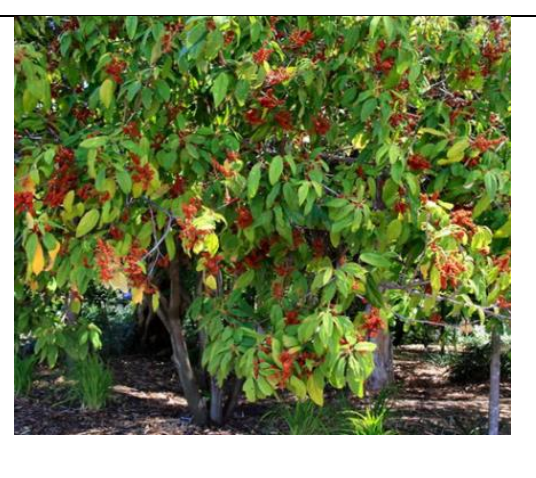 & $\begin{array}{l}\text { be ovate to lanceolate, cuneate to rounded with } \\
\text { two glands at base. Leaves are mostly acute at } \\
\text { apex, hairy and reddish, petiole } 1-4 \mathrm{~cm} \text { long, } \\
\text { puberulous. Male flowers are terminal and } \\
\text { axillary in position and } 2-10 \mathrm{~cm} \text { long. Fruit is } \\
\text { a depressed globose, } 3-\text { lobed capsule; stelate } \\
\text { puberulous with abundant orange or reddish } \\
\text { granules. Seeds are black in colour. }\end{array}$ & \\
\hline 9 & 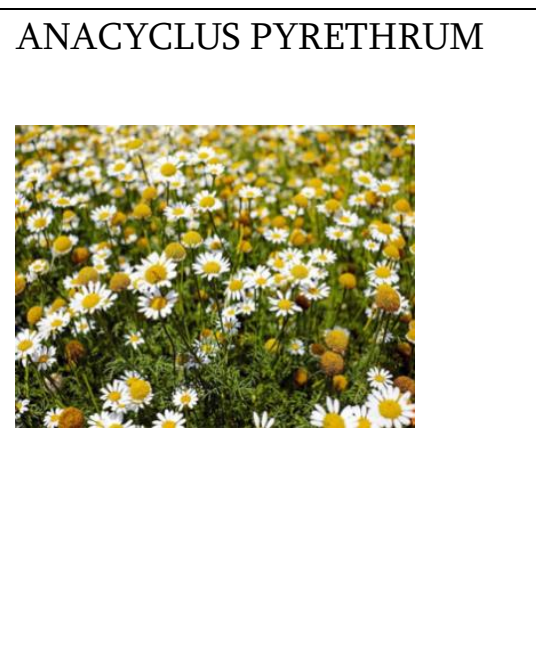 & $\begin{array}{l}\text { The stems lie on the ground, and rise erect } \\
\text { towards ends. Each of the stem bears one large } \\
\text { flower at branch ends, with yellow coloured } \\
\text { disk, white coloured rays and tinged with } \\
\text { purple beneath. Leaves are alternate, smooth } \\
\text { and pinnate. They are pale green in colour with } \\
\text { deeply cut segments. The root is somewhat } \\
\text { cylindrical in shape and slightly twisted. The } \\
\text { roots are often crowned with a cluster of grey } \\
\text { hairs. They are of brown colour with bright } \\
\text { black coloured spots on it. }\end{array}$ & Root \\
\hline 10 & 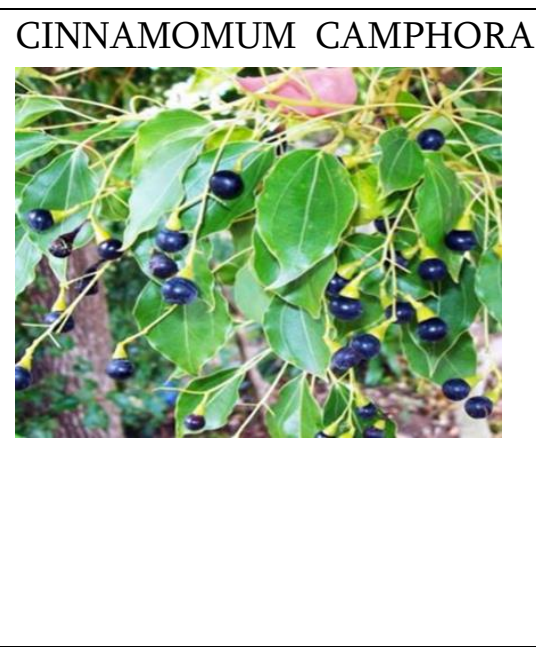 & $\begin{array}{l}\text { Karpura is a small, glabrous, broad leaved tree, } \\
\text { grow up to } 40 \mathrm{~m} \text { with a broad sweeping crown, } \\
\text { has diameter up to } 3 \mathrm{~m} \text {. Bark of the plant is } \\
\text { yellow brown colour with rough surface. } \\
\text { Trunk of the plant can grow up to } 8 \mathrm{~m} \text { long and } \\
2 \mathrm{~m} \text { wide. Leaves of the plants are dark to light } \\
\text { green colour with glossy light colour veins. } \\
\text { Leaves can vary in shape. The leaves grow } \\
\text { alternately on twigs. Flowers are bisexual and } \\
\text { white in colour. Fruits are in the form of dark } \\
\text { blueberries and are very small. }\end{array}$ & wood \\
\hline 11 & $\begin{array}{l}\text { ACORUS CALAMUS } \\
\text { ( }\end{array}$ & $\begin{array}{l}\text { Vacha has strong aromatic roots and long lesser } \\
\text { aromatic leaves. The aroma is used for making } \\
\text { perfumes. It is a soft plant of } 2 \text { - } 4 \mathrm{ft} \text { height. } \\
\text { Green coloured leaves with wavering edges are } \\
2 \text { - } 3 \mathrm{ft} \text { long and } 1 \text { inch in breadth. Flowers are } \\
\text { small, dense and whitish in colour. Fruits are } \\
\text { pulpy with numerous seeds. Its underground } \\
\text { hairy and brownish root resembles to ginger } \\
\text { rhizome. Leaves and roots of this plants are } \\
\text { aromatic. Plant with very strong aroma is } \\
\text { considered to be the best quality. }\end{array}$ & Rhizome \\
\hline
\end{tabular}




\begin{tabular}{|c|c|c|c|}
\hline 12 & 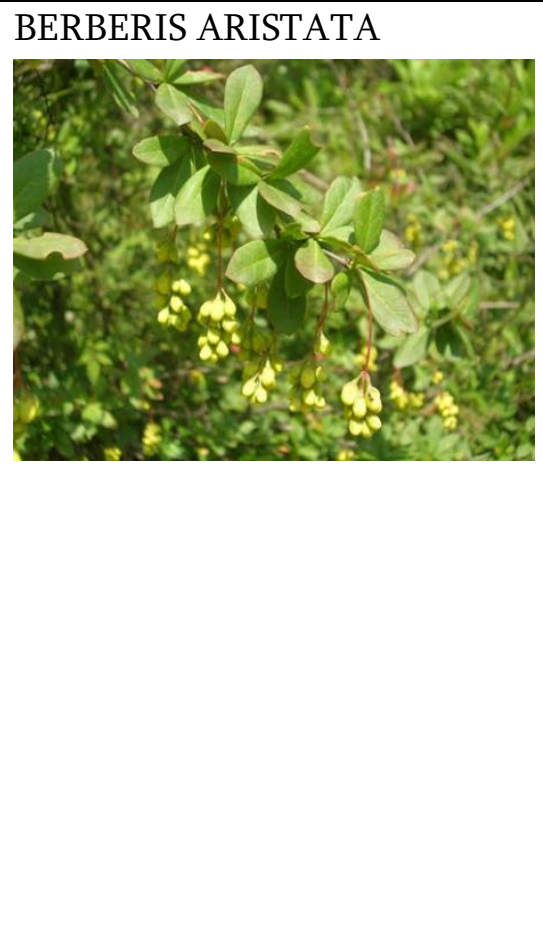 & $\begin{array}{l}\text { The plant is } 2-3 \mathrm{~m} \text { in height. It is a woody } \\
\text { plant with bark that appears yellow to brown } \\
\text { from outside and deep yellow inside. The bark } \\
\text { is covered with three branched thrones, which } \\
\text { are modified leaves and can be removed by } \\
\text { hand. } \\
\text { The leaves are arranged in tufts of } 5-8 \text { and } \\
4.9 \mathrm{~cm} \text { long and } 1.8 \mathrm{~cm} \text { broad. The leaves are } \\
\text { deep green dorsaly and light green ventraly. } \\
\text { Leaves show pinnate venation. Flowers are } \\
\text { yellow and are } 1.2 \mathrm{~cm} \text { in a racemose } \\
\text { inflorescences with } 11-16 \text { flowers arranged } \\
\text { along a central stem. The plant produces } \\
\text { bunches of succulent acidic and edible berries } \\
\text { which are bright red or pink in colour and } \\
7 \mathrm{~mm} \text { long, } 4 \mathrm{~mm} \text { diameter and weigh } 227 \mathrm{mg} \text {. }\end{array}$ & $\begin{array}{l}\text { Stem, } \\
\text { Fruit }\end{array}$ \\
\hline 13 & & $\begin{array}{l}\text { The clove tree is an evergreen tree that grows } \\
\text { up to } 8-12 \mathrm{~m} \text { tall, with large leaves and } \\
\text { crimson flowers grouped in terminal clusters. } \\
\text { The flower buds initially have a pale blue } \\
\text { colour, which gradually turn green, then } \\
\text { transition to a bright red when ready for } \\
\text { harvest. Cloves are harvested when they } \\
\text { become } 1.5-2 \mathrm{~cm} \text { in length, consisting of a long } \\
\text { calyx that terminates in four spreading sepals } \\
\text { and four unopened petals that form a small } \\
\text { central ball. }\end{array}$ & $\begin{array}{l}\text { Flower } \\
\text { buds }\end{array}$ \\
\hline 14 & 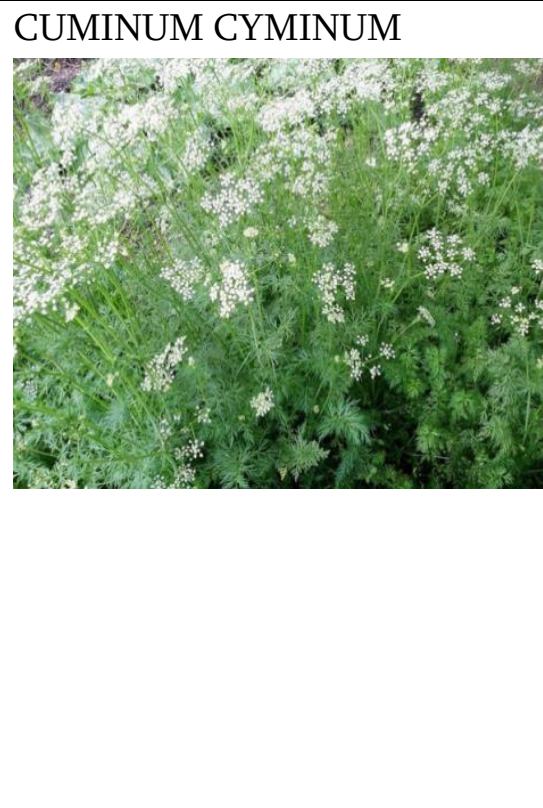 & $\begin{array}{l}\text { Cuminum cyminum is a small annual herb } \\
\text { which grows up to } 30-50 \mathrm{~cm} \text { in height. Its } \\
\text { leaves are alternate, compound. The leaves are } \\
5 \text { - } 10 \mathrm{~cm} \text { long and stem has grey or dark green } \\
\text { colour. The flowers are small white, found in } \\
\text { compound umbrella - like clusters. } \\
\text { The flowers have both male and female } \\
\text { structures together and an inferior ovary } \\
\text { develops into fruit. Fruits are greenish turns } \\
\text { grey when ripe, tapering towards both ends, } \\
\text { having } 4 \text { - } 5 \mathrm{~mm} \text { length, covered with pappus } \\
\text { hairs. These grain like fruits are called the } \\
\text { seeds, the true seeds are within them and come } \\
\text { out during germination through disintegration }\end{array}$ & Seeds \\
\hline
\end{tabular}




\begin{tabular}{|c|c|c|c|}
\hline & & of fruit wall. & \\
\hline 15 & NIGELLA SATIVA & $\begin{array}{l}\text { The flowers are delicate, and usually coloured } \\
\text { pale blue and white, with } 5-10 \text { petals. The } \\
\text { fruit is large and inflated capsule composed of } 3 \\
\text { - } 7 \text { united follicles, each containing numerous } \\
\text { seeds which are widely used as spices. The } \\
\text { flowers are hermaphrodites and are pollinated } \\
\text { by bees. Plant also has developed tap root. }\end{array}$ & Seed \\
\hline 16 & ASPARAGUS RACEMOSUS & $\begin{array}{l}\text { Asparagus racemosus is a herb common } \\
\text { throughout Nepal, Sri Lanka, and Himalayas of } \\
\text { India. It grows } 1 \text { - } 2 \mathrm{~m} \text { tall and prefers to take } \\
\text { root in gravelly, rocky soils high up in } \\
\text { Piedmont plains at } 1300 \text { - } 1400 \mathrm{~m} \text { elevation. } \\
\text { The plant is considered as an 'endangered' one } \\
\text { in its natural habitat due to habitat destruction. } \\
\text { Leaves are reduced to minute scales and spines. } \\
\text { It has adventitous root system with tuberous } \\
\text { roots that measure about } 1 \mathrm{~m} \text { in length, tapering } \\
\text { at both ends. It produces minute, white flowers } \\
\text { on short, spiky stems and fruits are blackish- } \\
\text { purple globular berries. }\end{array}$ & Root \\
\hline 17 & VANDA ROXBURGHII & $\begin{array}{l}\text { Vanda roxburghii is native to Uttar Pradesh } \\
\text { and West Bengal and widely found in the } \\
\text { southern states of India. It is an epiphyte } \\
\text { orchid with special whitish grey coloured } \\
\text { velamen roots for the absorption of water. } \\
\text { Leaves are succulent, } 15-20 \mathrm{~cm} \text { long, linear. The } \\
\text { flowers are in } 6 \text { - } 10 \text { flowered racemes. Sepals } \\
\text { are tessellated with brown lines and white } \\
\text { margins. Petals are yellow with brown lines } \\
\text { and white margins shorter than sepals. Lips are } \\
\text { bluish, dotted with purple and side lobes rising } \\
\text { from the mouth of the spur. Fruits are capsules } \\
\text { which are narrowly clavate - oblong with } \\
\text { acute ribs and shorter pedicel. }\end{array}$ & $\begin{array}{l}\text { Roots, } \\
\text { Leaves }\end{array}$ \\
\hline 18 & $\begin{array}{l}\text { TRACHYSPERMUM ROXBURG } \\
\text { HIANNUM }\end{array}$ & $\begin{array}{l}\text { Trachyspermum roxburghiannum is a } \\
\text { flowering plant that grow extensively in South } \\
\text { Asia, Southeast Asia and lndonesia. It is a plant } \\
\text { with lots of medicinal properties and is an }\end{array}$ & $\begin{array}{l}\text { Dried } \\
\text { fruits }\end{array}$ \\
\hline
\end{tabular}




\begin{tabular}{|c|c|c|c|}
\hline & $=-202$ & $\begin{array}{l}\text { active ingredient of several herbal medicines. } \\
\text { Ayamodakam is an erect, branched annual } \\
\text { herb , } 0.5-3 \text { feet tall. Stems are longitudinally } \\
\text { triped. Leaves are double - compound, with } \\
\text { linear segments. Flowers occur in compound } \\
\text { umbels. They have rounded white or pink } \\
\text { petals. Fruits are ovoid and yellowish. It is a } \\
\text { very strong spice, with a characteristic smell } \\
\text { similar to parsley. Flowering occurs from } \\
\text { December to February. }\end{array}$ & \\
\hline 19 & GLYCYRRHIZA GLABRA & $\begin{array}{l}\text { The plant grows to } 1 \mathrm{~m} \text { in height, with pinnate } \\
\text { leaves about } 7-15 \mathrm{~cm} \text { long, with } 9-17 \text { leaflets. } \\
\text { The roots are stoloniferous. The flowers are } 0.8 \\
-1.2 \mathrm{~cm} \text { long, purple to pale whitish blue, } \\
\text { produced in loose inflorescences. The fruit is an } \\
\text { oblong pod, } 2-3 \mathrm{~cm} \text { long, containing several } \\
\text { seeds. }\end{array}$ & $\begin{array}{l}\text { Roots / } \\
\text { Stolon }\end{array}$ \\
\hline 20 & PIPER CUBEBA & $\begin{array}{l}\text { Stem is jointed and roots arise from joints. The } \\
\text { leaves are } 4-6.5 \text { inch long and } 1.5-2 \text { inch } \\
\text { broad, ovate, oblong; long pointed and very } \\
\text { smooth. Flowers are arranged in narrow spikes } \\
\text { at the end of branches. Fruit is wrinkled, } \\
\text { rounded, light brown to dark brown and have a } \\
\text { long stalk. Pericarp is red to slightly brown, } \\
\text { testa are found to fuse with pericarp, fruit is } \\
\text { hard and has stony albumen which is white } \\
\text { and oily. It has got a characteristic taste, that is } \\
\text { slightly bitter and a pungent odour. }\end{array}$ & Fruits \\
\hline 21 & 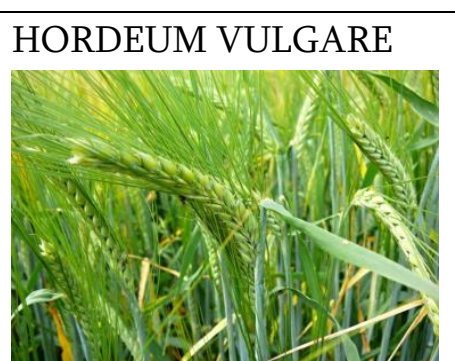 & $\begin{array}{l}\text { Fruits are caryopsis, elliptic, oblong, ovoid and } \\
\text { tapering at both ends, dorsally compressed and } \\
\text { flattened on the sides with a shallow } \\
\text { longitudinal furrow, ridged having shallow } \\
\text { depression between them; grains tightly } \\
\text { enclosed and adhering to the lemma and palea. }\end{array}$ & Husk \\
\hline
\end{tabular}




\section{RESULTS AND DISCUSSION}

\begin{tabular}{|c|c|c|c|c|}
\hline PLANT & FAMILY & PHYTOCHEMICAL & $\begin{array}{c}\text { PHARMACOLOGICAL } \\
\text { PROPERTY }\end{array}$ & REFERENCES \\
\hline $\begin{array}{l}\text { CINNAMOMUM } \\
\text { ZEYLANICUM }\end{array}$ & LAURACEAE & $\begin{array}{l}\text { Phytosterols, } \\
\text { Tannins, } \\
\text { Flavonoids, } \\
\text { Saponins, } \\
\text { Alkaloids, } \\
\text { Glycosides, } \\
\text { Terpinoids }\end{array}$ & $\begin{array}{l}\text { Antimicrobial, } \\
\text { Antidiabetic, } \\
\text { Antioxidant, } \\
\text { Anti inflammatory, } \\
\text { Antifungal }\end{array}$ & $\begin{array}{l}\text { Pandey and Gupta } \\
\text { (2014) }\end{array}$ \\
\hline $\begin{array}{l}\text { ELETTARIA } \\
\text { CARDAMOMUM }\end{array}$ & $\begin{array}{l}\text { ZINGIBERAC } \\
\text { EAE }\end{array}$ & $\begin{array}{l}\text { Alkaloids, } \\
\text { Glycosides, } \\
\text { Terpinoids, Steroids, } \\
\text { Protiens, } \\
\text { Carbohydrates } \\
\text { Phenolic compounds }\end{array}$ & $\begin{array}{l}\text { Antioxidant, } \\
\text { Antimicrobial, } \\
\text { Anti asthmatic, } \\
\text { Anti inflammatory }\end{array}$ & $\begin{array}{l}\text { Sivapala and } \\
\text { Jeyadevan (2012) } \\
\text { Chang et al., 2001 }\end{array}$ \\
\hline PIPER NIGRUM & PIPERACEAE & $\begin{array}{l}\text { Amides, Piperidines, } \\
\text { Pyrrolidines, Safrole }\end{array}$ & $\begin{array}{l}\text { Antimicrobial, } \\
\text { Antibacterial, } \\
\text { Antioxidant, } \\
\text { Anti inflammatory }\end{array}$ & $\begin{array}{l}\text { Kehimkarl, (2000) } \\
\text { Pundir et al., } \\
\text { (2010) }\end{array}$ \\
\hline PIPER LONGUM & PIPERACEAE & $\begin{array}{l}\text { Volatileoils, Starch, } \\
\text { Protiens } \\
\text { Saponins, } \\
\text { Carbohydrates, } \\
\text { Piperine, } \\
\text { Piper logumine }\end{array}$ & $\begin{array}{l}\text { Immuno modulatory effect, } \\
\text { Hypocholestrolaemic, } \\
\text { Anti asthmatic, } \\
\text { Anti amoebic }\end{array}$ & $\begin{array}{l}\text { Kehimkarl, (2000) } \\
\text { Pundir et al., } \\
\text { (2010) }\end{array}$ \\
\hline $\begin{array}{l}\text { ZINGIBER } \\
\text { OFFICINALE }\end{array}$ & $\begin{array}{l}\text { ZINGIBERAC } \\
\text { EAE }\end{array}$ & $\begin{array}{l}\text { Alkaloids, } \\
\text { Carbohydrates, } \\
\text { Glycosides, Protiens, } \\
\text { Saponins, Steroids, } \\
\text { Flavonoids }\end{array}$ & $\begin{array}{l}\text { Anti microbial, } \\
\text { Antioxidant, } \\
\text { Anti tumour, } \\
\text { Anti diabetic, } \\
\text { Anti emetic, } \\
\text { Anti inflammatory }\end{array}$ & $\begin{array}{l}\text { Chrubasik et al., } \\
\text { (2005) } \\
\text { Hassan( 2012) } \\
\text { Sahid, 2009 and } \\
\text { Shirazi, } 2007 \\
\text { Pandey and } \\
\text { Gupta, 2014 } \\
\text { Baliga and } \\
\text { Latheef, 2013 }\end{array}$ \\
\hline $\begin{array}{l}\text { ACONITUM } \\
\text { FEROX }\end{array}$ & $\begin{array}{l}\text { RANUNCULA } \\
\text { CEAE }\end{array}$ & $\begin{array}{l}\text { Toxic alkaloids, } \\
\text { Pseudoaconitin, } \\
\text { Indaconitine, } \\
\text { isoquinoline }\end{array}$ & $\begin{array}{l}\text { Antibacterial, } \\
\text { Antioxidant, } \\
\text { Anti pyretic, } \\
\text { Anti hypertensive, } \\
\text { Nephroprotective, } \\
\text { Anti inflammatory }\end{array}$ & $\begin{array}{l}\text { Rani et al., } 2013 \\
\text { Pieters and } \\
\text { Vielentick, } 2005\end{array}$ \\
\hline $\begin{array}{l}\text { MYRISTICA } \\
\text { FRAGRANS }\end{array}$ & $\begin{array}{l}\text { MYRISTICAC } \\
\text { EAE }\end{array}$ & $\begin{array}{l}\text { Limonene, Safrol, } \\
\text { Sabinene }\end{array}$ & $\begin{array}{l}\text { Antioxidant, } \\
\text { Antimicrobial, } \\
\text { Antibacterial, } \\
\text { Hypoglycemic }\end{array}$ & $\begin{array}{l}\text { Krishnakumari } \\
\text { and Thomas } \\
(2015) \\
\text { Ameen (2012) }\end{array}$ \\
\hline $\begin{array}{l}\text { MALLOTUS } \\
\text { PHILIPPENSIS }\end{array}$ & $\begin{array}{l}\text { EUPHORBIA } \\
\text { CEAE }\end{array}$ & $\begin{array}{l}\text { Amino acids, } \\
\text { Flavonoids, } \\
\text { Proteins, Saponins, } \\
\text { Steroids, Tannins, } \\
\text { Terpinoids }\end{array}$ & $\begin{array}{l}\text { Anti microbial, } \\
\text { Anti oxidant, } \\
\text { Anti viral, } \\
\text { Immunoregulatory, } \\
\text { Anti inflammatory }\end{array}$ & $\begin{array}{l}\text { Mital Patani et al., } \\
\text { (2011) }\end{array}$ \\
\hline
\end{tabular}




\begin{tabular}{|c|c|c|c|c|}
\hline $\begin{array}{l}\text { ANACYCLUS } \\
\text { PYRETHRUM }\end{array}$ & ASTERACEAE & $\begin{array}{l}\text { Steroids, } \\
\text { Triterpinoids, } \\
\text { Alkaloids, } \\
\text { Flavonoids, } \\
\text { Saponins, Tannins }\end{array}$ & $\begin{array}{l}\text { Anti microbial, } \\
\text { Anti bacterial }\end{array}$ & $\begin{array}{l}\text { Hanane et al., } \\
(2014) \\
\text { Tyagi and Ashim, } \\
2011 \\
\text { Sujith and Ronald, } \\
2011 . \\
\text { Shivakumar, } 2010\end{array}$ \\
\hline $\begin{array}{l}\text { CINNAMOMUM } \\
\text { CAMPHORA }\end{array}$ & LAURACEAE & $\begin{array}{l}\text { Cineol, Pinene, } \\
\text { Thymol, } \\
\text { Terpineol, Menthol, } \\
\text { Terpinoids }\end{array}$ & $\begin{array}{l}\text { Antioxidant, } \\
\text { Anti inflammatory, } \\
\text { Tyrosinase inhibition }\end{array}$ & Edeoga, 2005 \\
\hline $\begin{array}{l}\text { ACORUS } \\
\text { CALAMUS }\end{array}$ & ACORACEAE & $\begin{array}{l}\text { Asarone, Calacone, } \\
\text { Acorin, Starch, } \\
\text { Tannins }\end{array}$ & $\begin{array}{l}\text { Antidepressant, } \\
\text { Antihypertensive, } \\
\text { Anti diarrhoeal, } \\
\text { Antibacterial, } \\
\text { Antifungal }\end{array}$ & $\begin{array}{l}\text { Manikandan, } \\
(2005) \\
\text { Arinathan et al., } \\
(2003)\end{array}$ \\
\hline $\begin{array}{l}\text { BERBERIS } \\
\text { ARISTATA }\end{array}$ & $\begin{array}{l}\text { BERBERIDAC } \\
\text { EAE }\end{array}$ & $\begin{array}{l}\text { Alkaloids, Steroids, } \\
\text { Flavonoids, } \\
\text { Terpinoids, } \\
\text { Glycosides, Saponins }\end{array}$ & $\begin{array}{l}\text { Antihepato toxic, } \\
\text { Anti lipidemic, } \\
\text { Antibacterial, } \\
\text { Antioxidant }\end{array}$ & $\begin{array}{l}\text { Miana (1973) } \\
\text { Sahid, (2009) }\end{array}$ \\
\hline $\begin{array}{l}\text { SYZYGIUM } \\
\text { AROMATICUM }\end{array}$ & MYRTACEAE & $\begin{array}{l}\text { Eugenol, Tannins, } \\
\text { Flavonoids, } \\
\text { Triterpinoids, } \\
\text { Rahmnetin, } \\
\text { Eugenyl acetate }\end{array}$ & $\begin{array}{l}\text { Antibacterial, } \\
\text { Antifungal, } \\
\text { Anti thrombotic, } \\
\text { Anesthetic, } \\
\text { Anti inflammatory }\end{array}$ & Ghilani, 2005 \\
\hline $\begin{array}{l}\text { CUMINUM } \\
\text { CYMINUM }\end{array}$ & APIACEAE & $\begin{array}{l}\text { Cumin aldehyde, } \\
\text { Cymene, } \\
\text { Terpinoids }\end{array}$ & $\begin{array}{l}\text { Antimicrobial, } \\
\text { Antioxidant, } \\
\text { Effect on platelet function, } \\
\text { Analgesic activity }\end{array}$ & $\begin{array}{l}\text { Gohari and } \\
\text { Saeidnia (2011) } \\
\text { Shivakumar, 2010 }\end{array}$ \\
\hline $\begin{array}{l}\text { NIGELLA } \\
\text { SATIVA }\end{array}$ & $\begin{array}{l}\text { RANANCULA } \\
\text { CEAE }\end{array}$ & $\begin{array}{l}\text { Thymoquinone, } \\
\text { Dithymoquinon, } \\
\text { Thymohydroquinon } \\
\text { e }\end{array}$ & $\begin{array}{l}\text { Antioxidant, } \\
\text { Analgesic, } \\
\text { Hypotensive, } \\
\text { Gastrointestinal, } \\
\text { Antimicrobial }\end{array}$ & $\begin{array}{l}\text { Khare (2004) } \\
\text { Kris-Atherton } \\
\text { (2002) } \\
\text { Pund (2000) } \\
\text { Chowdhury, } \\
\text { (1998) } \\
\end{array}$ \\
\hline $\begin{array}{l}\text { ASPARAGUS } \\
\text { RACEMOSUS }\end{array}$ & LILIACEAE & $\begin{array}{l}\text { Phytosterol, } \\
\text { Triterpinoids, } \\
\text { Flavonoids, } \\
\text { Glycosides, } \\
\text { Fatty acids, } \\
\text { Saponins, Tannins }\end{array}$ & $\begin{array}{l}\text { Antibacterial, } \\
\text { Antimicrobial }\end{array}$ & $\begin{array}{l}\text { Marinova et al., } \\
2005\end{array}$ \\
\hline $\begin{array}{l}\text { VANDA } \\
\text { ROXBURGHII }\end{array}$ & $\begin{array}{l}\text { ORCHIDACE } \\
\text { AE }\end{array}$ & $\begin{array}{l}\text { Alkaloids, } \\
\text { Terpinoids, } \\
\text { Flavonoids, Phenols, } \\
\text { Tannins, Steroids }\end{array}$ & $\begin{array}{l}\text { Antipyretic, } \\
\text { Antioxidant, } \\
\text { Antibacterial, } \\
\text { Antifungal, } \\
\text { Antiulcer } \\
\end{array}$ & Simmler, (2010) \\
\hline $\begin{array}{l}\text { TRACHYSPERM } \\
\text { UM } \\
\text { ROXBURGHIAN } \\
\text { NUM }\end{array}$ & APIACEAE & $\begin{array}{l}\text { Alkaloids, } \\
\text { Flavonoids, } \\
\text { Steroids, Tannins, } \\
\text { Phenolic compounds }\end{array}$ & $\begin{array}{l}\text { Antioxidant, } \\
\text { Antihypertensive, } \\
\text { Antimicrobial, } \\
\text { Antispasmodic, } \\
\text { Broncho dialating activities }\end{array}$ & $\begin{array}{l}\text { Mathew, } 2008 \\
\text { Shirazi., (2007) }\end{array}$ \\
\hline
\end{tabular}




\begin{tabular}{|c|c|c|c|c|}
\hline $\begin{array}{l}\text { GLYCYRRHIZA } \\
\text { GLABRA }\end{array}$ & FABACEAE & $\begin{array}{l}\text { Alkaloids, } \\
\text { Glycosides, } \\
\text { Carbohydrates, } \\
\text { Flavonoids, } \\
\text { Saponins, } \\
\text { Proteins, Steroids, } \\
\text { Sterols, Lipids }\end{array}$ & $\begin{array}{l}\text { Antidepressant, } \\
\text { Antimicrobial, } \\
\text { Antioxidant, } \\
\text { Antiulcer, } \\
\text { Anti inflammatory, } \\
\text { Antidiabetic, } \\
\text { Hypolipidemic }\end{array}$ & $\begin{array}{l}\text { Shirazi, (2007) } \\
\text { Asif and } \\
\text { Khodadadi, } 2013 \\
\text { Gohari and } \\
\text { Saeidnia, (2011) }\end{array}$ \\
\hline PIPER CUBEBA & PIPERACEAE & $\begin{array}{l}\text { Alkaloids, } \\
\text { Monoterpenes, } \\
\text { Sesquiteroenes, } \\
\text { Oxides }\end{array}$ & $\begin{array}{l}\text { Antioxidant, } \\
\text { Antimicrobial, } \\
\text { Hepato protective, } \\
\text { Nephro protective, } \\
\text { Anti inflammatory } \\
\end{array}$ & $\begin{array}{l}\text { Prajapati, 2003; } \\
\text { Khare, 2004 } \\
\text { Ullah et al., } 2014\end{array}$ \\
\hline $\begin{array}{l}\text { HORDEUM } \\
\text { VULGARE }\end{array}$ & POACEAE & $\begin{array}{l}\text { Proteins, Phenolics, } \\
\text { Carbohydrates, } \\
\text { Flavonoids, } \\
\text { Tannins, Alkaloids, } \\
\text { Glycosides }\end{array}$ & $\begin{array}{l}\text { Glucose maintenance, } \\
\text { Anti alpha amylase } \\
\text { activity, } \\
\text { Antidiabetic }\end{array}$ & $\begin{array}{l}\text { Kris-Atherton } \\
\text { (2002) } \\
\text { Sujith and Ronald, } \\
2011 \\
\text { Tadeusz } \\
\text { Aniszewski, } 2007\end{array}$ \\
\hline
\end{tabular}

\section{IV.CONCLUSION}

The plant constituents used in the ayurvedic drug Vayugulika are immensely rich in several phytochemical compounds that show various pharmacological activities. Medicinal plants contains a variety of compounds such as alkaloids, tannins, flavonoids, phenols etc which might be responsible for the bacteriostatic and antimicrobial activity and therefore it is widely used in the treatment of urinary tract infections. They contain a number of bioactive compounds such as flavonoids which is responsible for its antibacterial and antioxidant property. Antioxidants are part of the body's defence system against free radical attack. It is also involved in the prevention of cellular damage which leads to pathways of aging and cancer.

The phytochemicals posses a wide range of medicinal properties, which may help in protection against various diseases. Flavonoids act as antioxidants, alkaloids protect against chronic diseases, saponins protect against hypercholesterolemia and steroids terpenoids show analgesic properties. Phytochemicals have an important role in preventing chronic diseases like cancer, diabetes and coronary heart diseases.
There are a number of clinical studies suggesting that the flavonoids are the main factors for the observed efficacy of these foods in reducing the incidence of chronic diseases including heart disease and some cancers. The present survey is a brief review of the promises plant polyphenols, bioactive components of our food, hold for the future.

The terpenoids display a wide range of biological activities against cancer, malaria, inflammation, and a variety of infectious diseases (viral and bacterial). Epidemiological and experimental studies suggest that mono-, di- and tri-terpenoids may be helpful in the prevention and therapy of several cancers, including mammary, skin, lung, for stomach, colon, pancreatic and prostate carcinomas.

So the medicinal properties of these plants can be attributed to its variety of active phytochemical constituents. Although these plants had received interest for the phytochemical investigations since many years, more work has to be done on its isolation and characterization. The results of this study may also be of commercial interest to research institutes and pharmaceutical industries in the development of 
new drugs. So characterization and isolation of the active chemical components possessed by these traditional plants for further study may lead to the development of a potential drug that may treat various kinds of infections and may lead to full utilization by the local community.

\section{REFERENCES}

[1]. Ameen S.O.2012. Antimicrobial activity of nutmeg extracts against Staphylococcus aureus and E. Coli. AI-TAOUANI, 25(2), 159-163.

[2]. Arinathan V., Mohan V. R. and De Britto A. J. 2003. Chemical composition of certain tribal pulses in South India, International Journal of Food Sciences and Nutrition, vol. 54, no. 3, 209 $-217$.

[3]. Asif M, and Khodadadi E.2013. Medicinal uses and chemistry of flavonoid contents of some common edible tropical plants. Journal of Paramedical Sciences 4, 3 ISSN 2008-4978 119.

[4]. Baliga, M. S, and Latheef, L. 2013. Ginger (Zingiber officinale) in the treatment and prevention of Arthritis. Bioactive Foods as Dietary Interventions for Arthritis and Related Inflammatory Diseases. 529-544.

[5]. Chang ST., Chang P. F., and Chang S.C. 2001. Antibacterial activity of leaf essential oils and their constituents from Cinnamomum. Journal Of Ethnopharmacology, 77, 1, 123 - 127.

[6]. Chowdhary.A.K.A.1998. Therapeutic potential of the volatile of Nigella sativa in monkey model with experimental shigellosis. Phytotherapy Research, 12(5), 361-636.

[7]. Chrubasik,S., Pittler, M. H. and Roufogalis, B. D. 2005. Zingiberis rhizoma: A comprehensive review on the ginger effects and efficiency profiles. Phytomedicine, 12: 684 -701.

[8]. Edeoga H.O. 2005. Petrochemical constituents of some Nigerian medicinal plants, African Journal of Biotechnology, vol-4(7), 685-688.
[9]. Ghilani A.H. 2005. Studies of the antihypertensive, antispasmodic, hepatoprotective activities of the seed extracts of Trachyspermum species. Journal of Ethno pharmacology, 98(12), 127-135.

[10]. Gohari A.R and Saeidnia S. 2011. A review on phytochemistry of Cuminum cyminum seeds and its standards from field to market. Pharmacognosy Journal, 3(15), 1-5.

[11]. Hanane E, Aminata S, and Fatima E. 2014. Phytochemical study of Anacyclus pyrethrum of Middle Atlas and in vitro study of antibacterial activity of A. Pyrethrum. Advances in Natural and applied science, 8(8), 131-140.

[12]. Kehimkarl I.2000. Common Indian Wild Flowers. Bombay Natural Historic Society. Published by Oxford University Press.

[13]. Khare C.P. 2004. Indian Medicinal Plants. An Illustrated Dictionary. Springer Science Business Media, LLC.

[14]. Kris-Atherton P.M. 2002. Bioactive compounds in foods: their role in the prevention of Cardiovascular diseases and cancer. American Journal of Medicine, 113(9), 71-88.

[15]. Krishnakumari S., and Thomas AR.,. 2015. Photochemical profiling of Myristica fragrans seed extract with different organic solvents. Asian Journal Pharmaceut Clinical Research, 8(1), 303-307.

[16]. Manikandan S.2005. Protective effects of Acorus calamus L. on free radical scavengers and lipid peroxidant in discrete regions of brain against noise stress exposed rat. Biological and Pharmaceutical Bulletin, 28(12), 2327-2330.

[17]. Marinova, Ribarova D. F. and Atanassova M.2005. Total phenolics and total flavonoids in Bulgarian fruits and vegetables, Journal of the University of Chemical Technology and Mettalurgy, 40, $255-260$. 
[18]. Mathew N. 2008. Antifilarial lead molecules isolated from Trachyspermum ammi, Molecules, 13, 2156-2168.

[19]. Miana GA. 1973. Tertiary dihydroprotoberbine alkaloids of Berberis species. Phytochemistry 12: 1822-1823.

[20]. Mital Patani, Jitendra Jain, Bhavna Marya, and Mandev Patel.2011. International Journal Of Pharmacy and Technology,3(1), 1867-1875.

[21]. Pandey, S., and Gupta R. K.,. 2014. Screening of nutritional, photochemical, antioxidant and antibacterial activity of Chenopodium album (Bathua) Journal of Pharmacognosy and Photochemistry, vol.3, 1-9.

[22]. Pieters L., and Vielentick A. J., 2005. Biological isolation of pharmacologically active plant components, still a valuable strategy for the finding of new bad compounds, Journal of Ethanopharmacology, 100(1-2), 57-60.

[23]. Prajapati N.D. 2003.Handbook of Medicinalplants. https://www.vedic books.net/hand.

[24]. Pund P. M., 2000. Some pharmacological studies on Nigella sativa Linn. With reference to its anti inflammatory activity. M.Sc. Thesis submitted to Dr. P. D.K.V. Akola P) 56-57.

[25]. Pundir, R. K, Jain, P, and Sharma, C. 2010. Antimicrobial Activity of Ethanolic Extracts of Syzygium aromaticum and Allium sativum Against Food Associated Bacteria and Fungi. Ethnobotanical Leaflets: 14: 344-60.

[26]. Rani S.K.S, Saxena N, and Udaysree. 2013. "Anti microbial activity of black pepper", Global Journal of Pharmacology, 7(1), 87 - 90.

[27]. Sahid M. 2009. Ethnobotanical studies on Barber is aristata DC root extracts. African Journal of Biotechnology, 8(4), 556-563.

[28]. Shirazi M.H. 2007. An evaluation of antibacterial activity of Glycyrrhiza glabra Linn extract on the growth of salmonella shigella and ETEC E. Coli. Journal of Biological Sciences, 7(5), 827-829.
[29]. Shivakumar SI .2010. Anti inflammatory activity of fruits of Cuminum cyminum Linn. Der Pharmacies Letter, 2(1), 22-24.

[30]. Simmler C.2010. Antioxidant biomarkers from Vanda stems reduce irradiated HaCaT PGE-2 production as a result of COX -2 inhibition, 5,13713 .

[31]. Sivapala SR, and Jeyadevan P.2012. Physicochemical and phytochemical study of rhizome of Cyperus rotundus linn. International Journal of Pharmacology and Pharmaceutical Technology (IJPPT),1(2);42-46.

[32]. Sujith K, and Ronald D.2011. Antioxidant activity of ethanolroot extract of Anacyclus pyrethrum. International Research Journal of Pharmacy, 2(12)222-226.

[33]. Tadeusz Aniszewski. 2007. Alkaloids - secrets of life alkaloid chemistry, biological significance, applications and ecological role. Elsevier publishers, Oxford, UK.

[34]. Tyagi S, and Ashim M.H. 2011. Antidiabetic effect of Anacyclus pyrethrum DC in Alloxan Induced Diabetic rats. European Journal of Biological Sciences, 3(4), 117-120.

[35]. Ullah, M.F., Bhat, S.H., Husain, E., Abu-Duhier, F., Hadi, S.M., Sarkar, F.H., and Ahmad, A. 2014. Cancer chemopreventive pharmacology of phytochemicals derived from plants of dietary and non-dietary origin: implication for alternative and complementary approaches. Phytochemistry Reviews 13(4):811-833.

\section{Cite this article as :}

Susan Jose, "A Review on The Phytochemical and Pharmacological Properties of The Ayurvedic Drug Vayugulika", International Journal of Scientific Research in Science, Engineering and Technology (IJSRSET), Online ISSN : 2394-4099, Print ISSN : 2395-1990, Volume 8 Issue 3, pp. 304-316, May-June 2021. Available at

doi : https://doi.org/10.32628/IJSRSET218356

Journal URL : https://ijsrset.com/IJSRSET218356 